\title{
Interactive Android Based Learning Media sebagai Inovasi Pembelajaran Membaca Bahasa Arab di Perguruan Tinggi: Desain Pengembangan Rekursif, Reflektif, dan Kolaboratif
}

\author{
Muhammad Alfan ${ }^{1}$, Moh. Khasairi ${ }^{2}$, Nurhidayati ${ }^{3}$, Laily Maziyah ${ }^{4}$ \\ ${ }^{1}$ Pendidikan Bahasa Arab-Universitas Negeri Malang
}

\begin{tabular}{l}
\hline INFO ARTIKEL \\
\hline Riwayat Artikel: \\
Diterima: $10-08-2020$ \\
Disetujui: $16-10-2020$ \\
\hline
\end{tabular}

Kata kunci:

learning media; interactive android; reading; arabic;

qiraah tsanawiyah media pembelajaran; android interaktif; membaca; bahasa arab; qiraah tsanawiyah

\begin{abstract}
This research was motivated by the decline in student motivation and achievement in Qiraah Tsanawiyah learning due to the monotonous appearance of the material and limited media innovation and learning time in the classroom. This study aims to develop interactive android learning media. This research method is research and development with the R2D2 model. This research produces interactive android media which contains four components, namely Al-Mufradat, Al-Qiraah Al-Jahriyah, Fahm Al-Maqru ', and Al-Tadrib, which help students improve five intensive reading skills in Arabic, namely understanding vocabulary, understanding sentence patterns, understanding sentence structure, determining main ideas, and mastering text content. The product of this development is suitable for use, both in terms of content, language, and graphics.
\end{abstract}

ABSTRAK

\begin{abstract}
Abstrak: Penelitian ini dilatarbelakangi oleh menurunnya motivasi dan prestasi mahasiswa dalam perkuliahan Qiraah Tsanawiyah disebabkan monotonnya tampilan materi dan terbatasnya inovasi media dan waktu pembelajaran di kelas. Penelitian ini bertujuan untuk mengembangkan media pembelajaran android interaktif. Metode penelitian ini adalah penelitian dan pengembangan dengan model R2D2. Penelitian ini menghasilkan media android interaktif yang berisi empat komponen, yaitu AlMufradat, Al-Qiraah Al-Jahriyah, Fahm Al-Maqru', dan Al-Tadrib yang membantu mahasiswa meningkatkan lima keterampilan membaca intensif bahasa Arab, yaitu memahami kosakata, memahami pola kalimat, memahami struktur kalimat, menentukan ide pokok, dan menguasai isi teks. Produk pengembangan ini layak digunakan, baik dari aspek isi, bahasa, maupun grafis.
\end{abstract}

\section{Alamat Korespondensi:}

Muhammad Alfan

Pendidikan Bahasa Arab

Universitas Negeri Malang

Jalan Semarang 5 Malang

E-mail: muhammad.alfan.fs@um.ac.id

Perkembangan ilmu pengetahuan dan teknologi melahirkan produk canggih dan unggul dalam berbagai bidang kehidupan, tak terkecuali bidang pendidikan. Pendidikan di era ini terus meningkatkan kualitasnya dalam berbagai aspek, terutama aspek pembelajaran. Gaya pembelajaran saat ini adalah pembelajaran digital. Pembelajaran digital adalah pembelajaran yang memanfaatkan produk teknologi sebagai media untuk mempelajari dan mengajarkan materi. Pembelajaran di era sekarang telah memanfaatkan media produk teknologi semaksimal mungkin. Pembelajaran di tingkat dini hingga perguruan tinggi telah mengeksplorasi produk teknologi sebagai media belajar dan mengajar.

Media pembelajaran kini dapat kita temukan dengan mudah. Di antara media digital yang sudah marak digunakan dalam pembelajaran adalah internet, android, smartphone, komputer, laptop, multimedia, media interaktif, dan media elektronik lainnya. Beberapa penelitian menjadi bukti bahwa pembelajaran digital ini sudah menjadi trend di seluruh lembaga pendidikan di Indonesia (Kusumadewi \& Ulhusna, 2019), (Dariyadi, 2019), (Maita, Zarnelly, \& Adawiyah, 2018), (Putri \& Billah, 2019), dan (Suaibah \& Rahman, 2020). Pembelajaran digital terbukti efektif untuk diterapkan. Penelitian yang dilakukan oleh Lin, Chen, dan Liu membuktikan bahwa pembelajaran digital lebih menunjukkan dampak positif dari pada pembelajaran tradisional. Penelitian tersebut menunjukkan hasil bahwa pembelajaran digital membawa efek positif bagi variabel hasil belajar dan variabel motivasi belajar (Lin et al., 2017). 
Seiring dengan berjalannya waktu produk media digital yang lahir akibat pesatnya perkembangan teknologi semakin banyak dan beragam. Perkembangan yang pesat dalam bidang media digital tersebut mengakibatkan penggunaan media digital itu menjadi suatu hal yang biasa bahkan terkadang sering membosankan jika daya kreativitas dan inovasi media digital tersebut tidak ditingkatkan. Oleh karena itu, dalam artikel ini penulis mengembangkan sebuah media pembelajaran digital yang dikemas dalam bentuk media interaktif. Penulis mengembangkan media berupa android berbasis interaktif karena penggunaan android sudah menjadi suatu hal yang biasa dan akan membosankan jika daya kreativitas dan inovasinya tidak ditingkatkan. Media interaktif membuat proses pembelajaran lebih menarik karena gambar-gambar ilustrasi cerita, suara dan text dapat terintegrasi dan dapat dikendalikan sesuai keinginan (Arindiono \& Ramadhani, 2013).

Pengembangan media android interaktif dalam artikel ini digunakan untuk media pembelajaran Qiraah Tsanawiyah (Intermediate Reading) di Program Studi (prodi) S-1 Pendidikan Bahasa Arab (PBA) Universitas Negeri Malang. Pada prodi ini, keterampilan membaca diajarkan emapt kali secara berjenjang selama masa studi, yaitu Qiraah Ibtidaiyah (Basic Reading), Qiraah Tsanawiyah (Intermediate Reading), Qira'ah Syamilah (Comprehensive Reading), dan Qiraah Muwassaah (Expanded Reading). Pemilihan matakuliah Qiraah Tsanawiyah sebagai objek penelitian pengembangan media ini dilatarbelakangi oleh hasil pengamatan selama mengajar, sharing pengalaman bersama dosen pengampu yang lain, dan perbandingan prestasi dan motivasi belajar antara matakuliah Qiraah Ibtidaiyah dan Qiraah Tsanawiyah.

Berdasarkan pengalaman mengajar matakuliah Qiraah Tsanawiyah berturut-turut selama enam semester, mahasiswa mengalami penurunan dibandingkan ketika mereka mengikuti perkuliahan Qiraah Ibtidaiyah. Saat mengikuti perkuliahan Qiraah Ibtidaiyah pada semester pertama, mahasiswa lebih cepat dalam memahami teks dan tidak ada kendala serius dalam mengerjakan latihan-latihan terkait membaca. Namun, begitu mengikuti matakuliah Qiraah Tsnawiyah pada semester kedua, mahasiswa tampak kaget ketika dihadapkan dengan teks yang lebih panjang dan banyak daripada teks Qiraah Ibtidaiyah. Sementara jam atau waktu perkuliahan dalam satu pertemuan terbatas. Berdasarkan pengalaman, sering kali untuk membahas teks tersebut dalam satu pertemuan di dalam kelas tidak cukup. Oleh karena itu, diperlukan media yang dapat memungkinkan membaca teks tersebut dimanapun dan kapanpun mahasiswa berada supaya dapat menuntaskan teks bacaan berdasarkan tuntutan kurikulum. Pengembangan media interaktif android ini dianggap sesuai dengan karakteristik keterampilan membaca yang notabenenya merupakan keterampilan reseptif yang menuntut mahasiswa untuk membaca secara mandiri karena media Interactive Android Based Learning ini dapat diakses secara individu di manapun dan kapanpun pengguna berada. Di samping itu media ini sangat praktis karena ringan dan mudah dibawa kemana saja. Dengan adanya media ini diharapkan mahasiswa termotivasi, meningkat minatnya dalam membaca, dan prestasi membacanya tidak menurun.

Ada beberapa penelitian yang sudah dilakukan terkait topik ini. Penelitian-penelitian tersebut dapat diklasifikasikan menjadi tiga kategori, yaitu (1) penelitian terkait pembelajaran Qiraah (Membaca Bahasa Arab) namun tidak terkait media (Hendrawanto, 2020) dan (Ni'mah, Rizki, Ismawati, 2020); (2) penelitian terkait pengembangan media pembelajaran namun tidak untuk pembelajaran Qiraah (Kusumadewi \& Ulhusna, 2019), (Maita, Zarnelly, \& Adawiyah, 2018), (Putri \& Billah, 2019), dan (Suaibah \& Rahman, 2020); (3) penelitian terkait pengembangan media untuk pembelajaran Qiraah (Wijoyo, 2016) dan (Haniifah, Kuswardono, Zukhaira, 2020). Dari tiga kategori penelitian tersebut yang dapat dianggap memiliki keterkaitan erat dengan penelitian dalam artikel penulis adalah kategori dua dan tiga. Oleh karena itu, penulis akan membandingkan penelitiannya dengan kategori dua dan tiga ini.

Perbandingan penelitian ini dengan dua kategori penelitian di atas dapat kita lihat dari empat aspek, yaitu (1) jenis media yang dikembangkan, (2) subjek pengguna media, (3) muatan materi dalam media, dan (4) model pengembangan. Dari aspek media yang dikembangkan, penelitian ini bertujuan mengembangkan media android interaktif, sedangkan penelitian (Kusumadewi \& Ulhusna, 2019; Maita, Zarnelly, \& Adawiyah, 2018; Wijoyo, 2016; Haniifah, Kuswardono, Zukhaira, 2020) keempatnya tidak mengembangkan media android interaktif. Jadi, penelitian ini berbeda dari empat penelitian tersebut dari aspek jenis media yang digunakan. Adapun jika dibandingkan dengan dua penelitian lainnya, yaitu penelitian Putri \& Billah dan Suaibah \& Rahman, penelitian ini memiliki kesamaan, yaitu sama-sama mengembangkan media android, namun perbedaannya ada pada jenis media androidnya, yaitu media android yang dikembangkan dalam penelitian ini bersifat interaktif, sedangkan pada penelitian Putri \& Billah dan Suaibah \& Rahman tidak bersifat interaktif. Dari aspek subjek pengguna media, penelitian ini diperuntukkan bagi mahasiswa jurusan bahasa Arab di perguruan tinggi, sedangkan enam penelitian tersebut tidak diperuntukkan bagi mahasiswa jurusan bahasa Arab, melainkan untuk siswa sekolah dan mahasiswa tetapi bukan jurusan bahasa Arab. Dari aspek muatan materi dalam media, materi dalam media android interaktif pada penelitian ini adalah membaca bahasa Arab tingkat intermediate yang terdiri atas kumpulan teks bacaan yang dikembangkan berdasarkan hasil analisis kebutuhan pembelajaran, sedangkan dari enam penelitian di atas dua penelitian yang terkait media Qiraah, yaitu penelitian Wijoyo (2016); Haniifah, Kuswardono, \& Zukhaira (2020) keduanya mengembangkan media untuk pembelajaran bahasa Arab di sekolah, sedangkan empat penelitian lainnya, yaitu penelitian Kusumadewi \& Ulhusna (2019) mengembangkan media yang memuat materi istima' (menyimak Bahasa Arab) untuk siswa sekolah, dan tiga penelitian sisanya mengembangkan media yang memuat materi bahasa Arab dasar untuk mahasiswa jurusan non bahasa Arab. 
Dari aspek model pengembangan, penelitian ini menggunakan model pengembangan R2D2 (Recursive \& Reflective Design and Development), sedangkan enam penelitian pengembangan di atas semua tidak menggunakan model khusus, melainkan menggunakan langkah-langkah penelitian pengembangan secara umum. Berdasarkan hasil paparan ini dapat disimpulkan bahwa penelitian ini berbeda dengan beberapa penelitian terdahulu dari empat aspek, yaitu (1) jenis media yang dikembangkan, (2) subjek pengguna media, (3) muatan materi dalam media, dan (4) model pengembangan.

Beberapa penelitian di atas telah membuktikan bahwa penggunaan media digital efektif untuk diterapkan dalam pembelajaran bahasa Arab. Pembelajaran Qiraah yang dilaksanakan penulis selama ini juga sudah memanfaatkan beberapa media digital, terutama android, namun pembelajaran yang berlangsung pada Qiraah tingkat intermediate (Qiraah Tsnawiyah) mengalami sedikit penurunan dibanding saat pembelajaran Qiraah Ibtidaiyah. Hal ini salah satunya disebabkan oleh penggunaan media digital yang belum interaktif. Oleh karena itu, penelitian ini bertujuan untuk mengembangkan media pembelajaran digital berupa media android interaktif guna meningkatkan motivasi dan prestasi belajar dalam mata kuliah Qiraah Tsanawiyah yang diindikasi menurun dari motivasi dan prestasi belajar saat mengikuti perkuliahan Qiraah Ibtidaiyah. Meskipun latar penelitiannya di Prodi S-1 PBA UM, namun hasil pengembangan media dalam penelitian ini dapat dimanfaatkan oleh semua lembaga pendidikan di Indonesia, khususnya prodi S-1 PBA karena muatan materi yang dikembangkan merujuk pada kitab Al-'Arabiyah Baina Yadaik Jilid 2 yang merupakan salah satu buku ajar yang digunakan oleh hampir semua lembaga pendidikan yang mengajarkan bahasa Arab.

\section{METODE}

Penelitian ini menggunakan metode penelitian pengembangan atau biasa disebut $R \& D$ (Research and Development) guna menghasilkan produk media pembelajaran interaktif berbasis android untuk matakuliah Qiraah Tsanawiyah. Model pengembangan yang digunakan adalah R2D2. Pemilihan model R2D2 ini dikarenakan model ini bersifat lentur, fleksibel, dan tidak kaku sehingga langkah-langkah pada saat pengembangan tidak harus bersifat prosedural, tetapi dapat menyesuaikan situasi dan kondisi saat melakukan pengembangan. Di samping itu,

model R2D2 ini bersifat recursive dan reflective, artinya proses penetapan spesifikasi produk pengembangan ini dilakukan berulang-ulang dengan menyesuaikan kebutuhan pengguna sehingga menghasilkan draf desain produk yang tepat, mantap, dan bermutu. Selain itu, model ini juga bersifat kolaboratif, artinya dalam mengembangkan produk, peneliti bekerja sama dengan tim partisipan yang terdiri atas peneliti, tim ahli, dan calon pengguna produk baik dosen maupun mahasiswa. Dengan melibatkan tim partisipan maka pengembangan diharapkan dapat menghasilkan produk yang tepat efektif, efisien, dan relevan dengan kebutuhan pengguna (Alfan, 2018).

Model pengembangan R2D2 terdiri atas tiga tahap utama, yaitu define (penetapan draft desain produk), design \& development (penyusunan dan pengembangan draft desain produk), dan dissemination (sosialisasi hasil pengembangan) (Rayanto, 2018). Penelitian ini hanya dilakukan sampai dua tahap, yaitu tahap define dan tahap design \& development, namun pada tahap design \& development, peneliti tidak melakukan uji coba produk karena penelitian ini memang dibatasi sampai tahap menghasilkan produk saja tanpa harus uji coba produk. Di samping itu, uji coba dalam model ini tidak menjadi suatu hal yang wajib karena proses pengembangan sudah dilakukan secara rekursif, reflektif, dan kolaboratif sebagaimana penjelasan di atas Setelah dimodifikasi sesuai kebutuhan maka prosedur pengembangan penelitian menggunakan model R2D2 ini terdiri atas dua tahap, yaitu tahap define yang terdiri atas tiga langkah, yaitu (1) menentukan spesifikasi produk, (2) menyusun draf desain produk, dan (3) review tim partisipan. Sementara itu, tahap design \& development yang terdiri atas dua langkah, yaitu (1) menyempurnakan draf desain produk dan (2) penyusunan produk. Jadi dalam pengembangan ini ada dua fokus, yaitu fokus penetapan (define) dan fokus penentuan desain dan pengembangan (design \& development).

\section{HASIL}

Hasil dari penelitian pengembangan ini adalah media android interaktif untuk pembelajaran Qiraah Tsanawiyah di Program Studi S-1 PBA UM. Qiraah Tsanawiyah adalah matakuliah membaca intensif bahasa Arab tingkat intermediate atau menengah yang ditempuh mahasiswa pada semester dua. Media ini berupa aplikasi android yang dapat diakses baik secara online maupun offline dengan cara mengunduh aplikasinya terlebih dahulu. Media ini dapat dibuka menggunakan media smartphone maupun laptop. Media ini mudah diakses karena ukuran filenya tidak besar, hanya 51,9 MB dengan versi 1.0.

Media ini dapat digunakan juga secara luas baik di perguruan tinggi seluruh Indonesia maupun di seluruh dunia karena muatan materi di dalamnya bersumber dari buku ajar bahasa Arab bernama Al-Arabiyah baina Yadaika yang jilid kedua. Kitab ini merupakan salah satu buku ajar rujukan bagi lembaga-lembaga pendidikan di Indonesia bahkan di seluruh dunia yang mengajarkan bahasa Arab, baik di tingkat perguruan tinggi, pondok pesantren, maupun madrasah tingkat aliyah yang kurikulumnya sesuai dengan kitab tersebut.

Jika sudah didownload, tampak icon media ini. Icon media ini adalah gambar huruf dhadh (ض) berwarna putih dalam lingkaran bernuansa biru gelap dan bermotif sehingga menambah kecerahan dan kejelasan huruf dhadh sebagai lambang yang berwibawa bagi media ini. Tampilan icon media ditunjukkan pada gambar 1. 


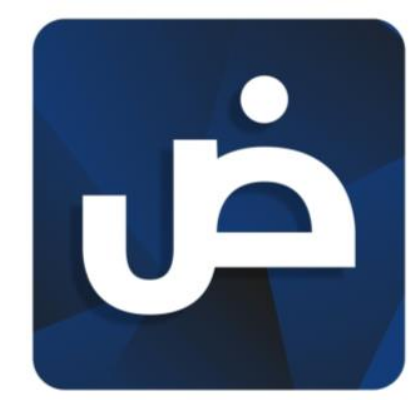

\section{Gambar 1. Icon Media}

Cara membuka aplikasi ini adalah dengan cara klik icon yang berlambang huruf $d$ hadh tersebut. Begitu icon diklik maka akan muncul tampilan pertama dari media ini, yaitu cover media. Berikut tampilan cover media.

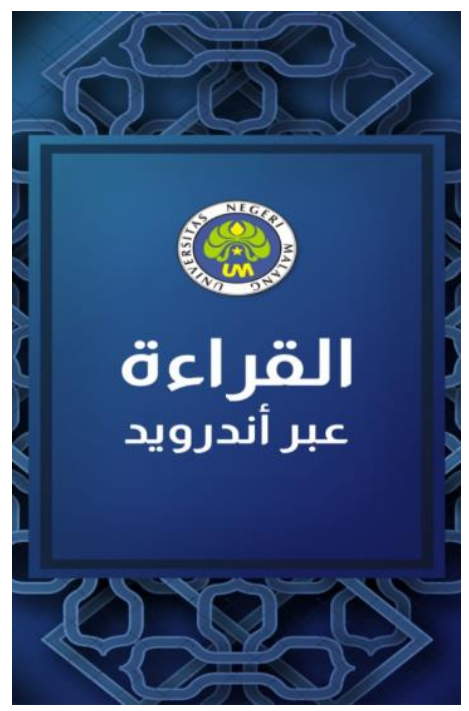

\section{Gambar 2. Cover media}

Setelah tampilan cover terbuka beberapa saat, maka akan muncul dengan sendirinya tampilan isi media ini. Dalam tampilan ini tampak di bagian bawah ada empat menu utama media, yaitu المفردات (Al-Mufradat), القراءة الجهرية (Al-Qiraah AlJahriyah), فهم المقروء (Fahm Al-Maqru'), dan التدريب (Al-Tadrib). Setiap menu ini memiliki icon juga yang sesuai dengan isinya. Pada tampilan ini juga langsung tampak isi dari menu pertama, yaitu المفردات. Berikut tampilan menu media.

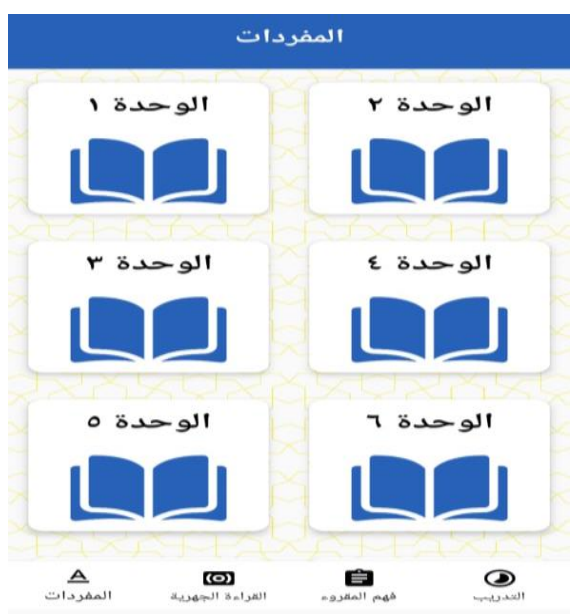

Gambar 3. Menu media 
Keempat menu tersebut jika kita buka maka akan kita dapati program kegiatan membaca bahasa Arab di dalamnya berdasarkan topik teks bacaan. Pada menu Al-Mufradat terdapat 12 sub menu unit bacaan (Al-Wihdah). Judul sub menu unit bacaan tersebut ditulis secara urut dalam bahasa Arab dari kiri ke kanan, seperti pada tampilan 3 di atas.

Jika kita buka setiap menu unit bacaan pada menu utama Al-Mufradat, maka akan kita dapati isinya, yaitu penyajian materi mufradat (kosakata) menggunakan gambar dan menggunakan kamus. Namun ada juga yang hanya menggunakan gambar saja, seperti pada unit bacaan 1, karena semua kosakata dapat dijelaskan dengan gambar sehingga tidak diperlukan kamus. Jadi tergantung dari tingkat kemungkinan makna kosakata untuk divisualisasikan melalui gambar. Jika tidak mungkin, maka dijelaskan dengan makna dari kamus. Kamus yang digunakan dalam menerjemahkan kosakata baru adalah kamus elektronik yaitu https://almaany.com dan kamus pendamping kitab Al-Arabiyah Baina Yadaik. Jumlah kosakata setiap unit bacaan berbeda tergantung materi pada masing-masing unit bacaan. Berikut tampilan isi sub menu Al-Mufradat.

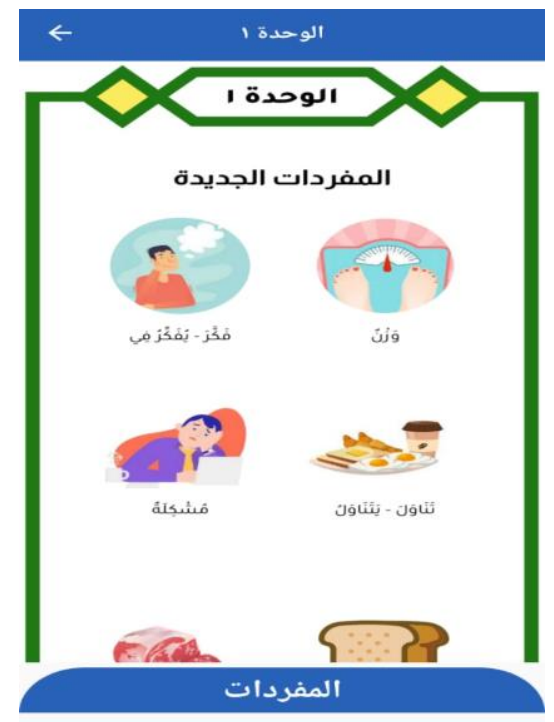

\section{Gambar 4. Contoh isi sub menu Al-Mufradat}

12 sub menu Al-Mufradat tadi bisa kita buka satu persatu. Jika kita sudah selesai membaca satu sub menu Al-Mufradat, maka kita bisa segera pindah ke sub menu yang lain atau menu utama yang lain dengan cara klik tanda panah di pojok atas sebelah kiri.

Di sebelah kanan menu Al-Mufradat adalah menu Al-Qiraah Al-Jahriyah. Sama dengan menul Al-Mufradat, ketika kita klik menu Al-Qiraah Al-Jahriyah, maka akan muncul 12 sub menu yang tertulis dengan bahasa Arab yang menunjukkan nomor unit bacaan secara urut dari kiri ke kanan, dari Al-wihdah 1 (unit bacaan 1) sampai Al-wihdah 12 (unit bacaan 12) seperti pada gambar 3 di atas. Setiap menu berisi tiga materi audio membaca nyaring bahasa Arab (Qiraah Jahriyah), yaitu audio alif (') $b a^{\prime}$ (ب), dan jim (ج). Di atas tiga audio tersebut tertulis instruksi berbahasa Arab yang artinya adalah petunjuk untuk mengklik/memilih salah satu audio sesuai keinginan. Begitu klik salah satu audio maka akan terdengar materinya. Audio pada poin alif berisi audio contoh membaca kalimat secara nyaring. Audio pada poin $b a^{\prime}$ berisi audio contoh membaca gambar secara nyaring. Audio pada poin jim berisi audio contoh membaca teks bacaan secara nyaring. Ketika kita sudah selesai menggunakan audio tersebut maka kita klik tanda panah di pojok atas sebelah kiri untuk kembali ke sub menu dalam menu Al-Qiraah AlJahriyah atau ke menu utama lain. Berikut contoh tampilan isi sub menu Al-Qiraah Al-Jahriyah.

Menu ketiga dari media ini adalah menu Fahm Al-Maqru' yang terletak sebelah kanan menu Al-Qiraah Al-Jahriyah. Pada menu ini terdapat 12 sub menu yang tertulis dengan bahasa Arab yang menunjukkan nomor unit bacaan dan di bawahnya tertulis judul unit bacaan. 12 sub menu ini diatur secara urut dari bawah ke atas dengan warna biru dan hijau secara bergantian seperti tampak pada gambar 5 .

Cara membuka setiap sub menu adalah dengan cara klik sebagaimana pada menu-menu sebelumnya. Isi setiap sub menu adalah teks bacaan yang sesuai dengan judul unit bacaan. Setiap paragraf dalam teks diberi gambar yang sesuai isi paragraf. Berikut gambar contoh tampilan isi sub menu Fahm Al-Maqru'. 


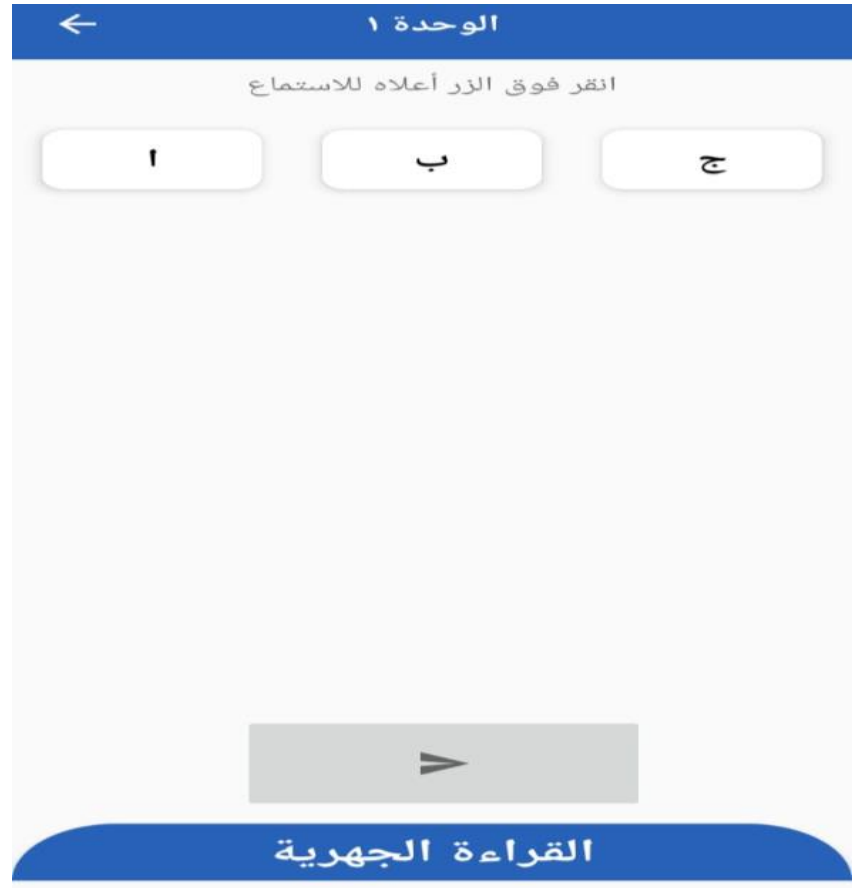

Gambar 4. Contoh isi sub menu Al-Qiraah Al-Jahriyah

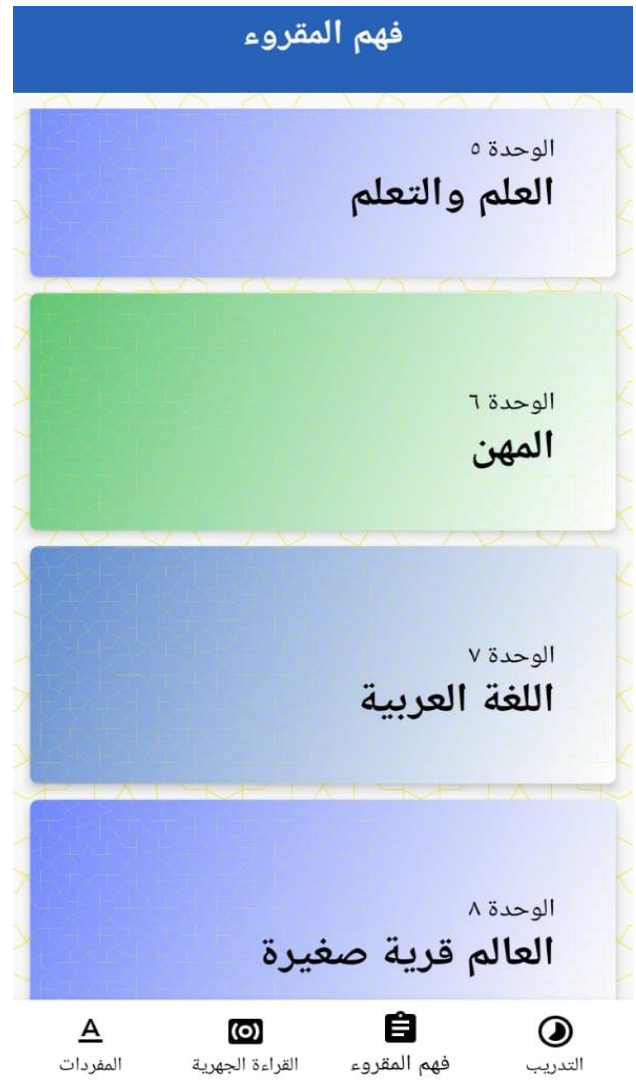

Gambar 5. Menu Al-Qiraah Al-Jahriyah 


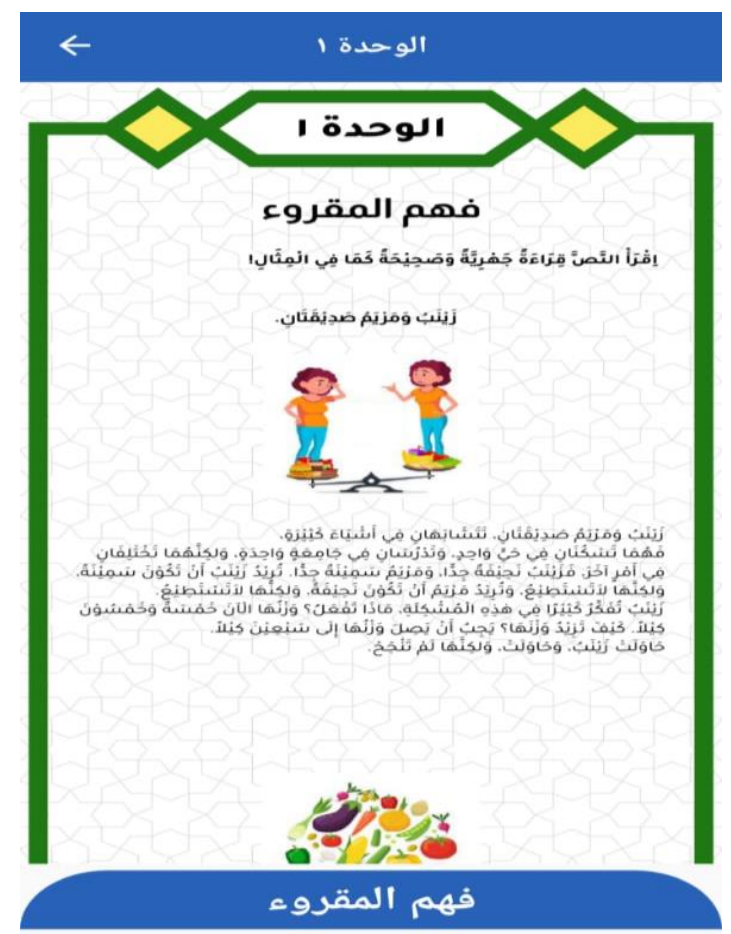

Gambar 6. Contoh isi sub menu Fahm Al-Maqru'

Menu keempat atau menu terakhir dalam media ini adalah menu Al-Tadrib. Sama dengan menu-menu sebelumya, menu ini berisi 12 unit bacaan yang tertulis dengan bahasa Arab dengan lambang buku dan alat tulis. 12 sub menu ditata secara urut dari kiri ke kanan mulai sub menu 1 sampai sub menu 12. Di atas sub-sub menu tertulis kalimat اختبر نفسك (Ikhtabir nafsak) yang artinya adalah "uji dirimu" yang menggambarkan bahwa menu ini adalah menu untuk mengerjakan latihan-latihan membaca intensif bahasa Arab. Jika kita klik satu sub menu maka akan muncul dua atau tiga latihan membaca. Berikut tampilan menu dan isi sub menu Al-Tadrib.

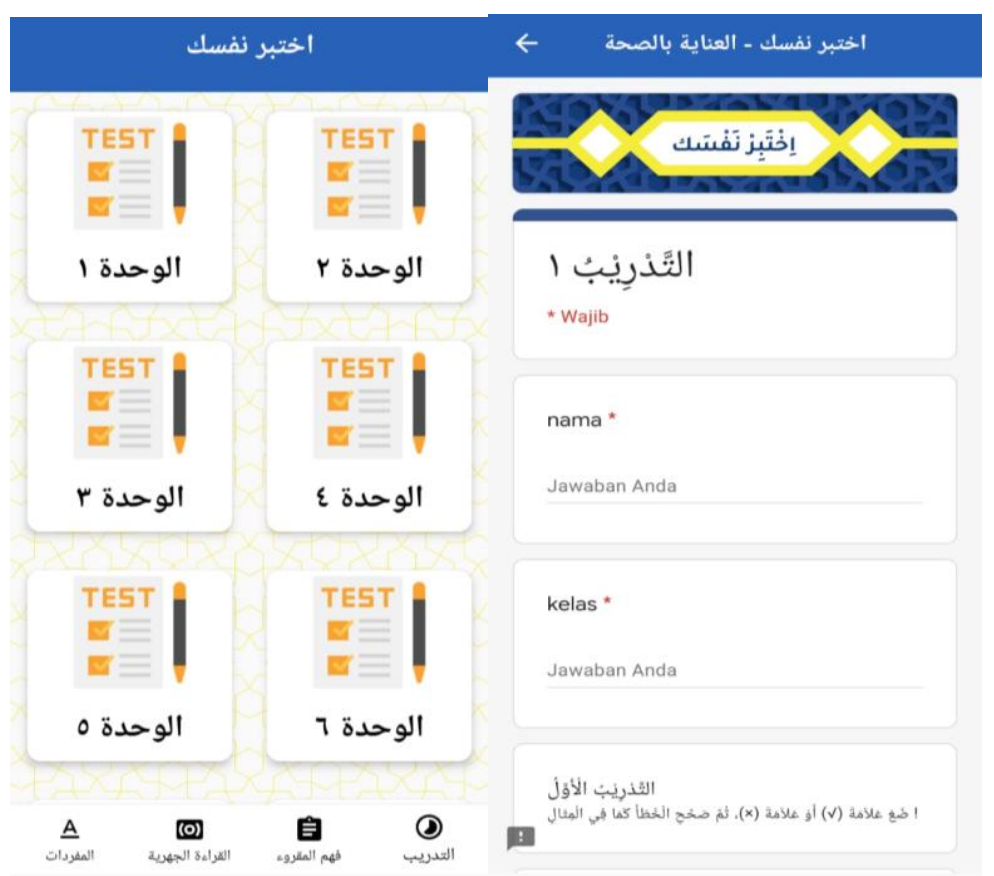

Gambar 7. menu dan isi sub menu Al-Tadrib 


\section{PEMBAHASAN}

Interactive Android Based Learning Media sebagai inovasi pembelajaran membaca bahasa arab tingkat intermediate (Qiraah Tsanawiyah) adalah produk yang telah dihasilkan dalam pengembangan ini. Kemahiran Qiraah Tsanawiyah di prodi S1 PBA UM diajarkan pada semester kedua. Media ini memiliki karakteristik dari aspek isi, bahasa, dan grafis.

Dari aspek isi, media android interaktif ini terdiri atas 12 unit bacaan (wihdah), yaitu Zainab wa Maryam Shodiqatani, Anwa' Al-Tarwih, Limadza Yufadhdhilu ba'dh Al-Nas Al-Hayah fi Al-Mudun Al-Kabirah, Al-Ta'lim baina Al-Madhi wa AlHadhir, 'Amal Al-Mar'ah, Al-'Arabiyah Al-Fashihah wa Atsaruha, Wasail Al-Naql wa Al-Ittishal Qadiman wa Haditsan, AlIslam wa Al-Thaharah, Haqiqat Al-Islam, Marhalat Al-Syabab, Mizat Al-'Alam Al-Islamiy, dan Anwa' Talawwuts Al-Bi'ah. Semua unit bacaan ini diambil dari Kitab Al- 'Arabiyah Baina Yadaik Jilid 2. Penentuan jumlah 12 unit bacaan ini menyesuaikan 12 jumlah pertemuan dari 16 jumlah pertemuan selama satu semester karena yang empat pertemuan digunakan untuk membahas rencana perkuliahan semester dan melaksanakan kontrak perkuliahan pada pertemuan pertama, Ujian Tengah Semester (UTS) pada pertemuan kedelapan, membahas hasil UTS pada pertemuan kesembilan, dan ujian akhir semester pada pertemuan keenambelas.

Setiap unit bacaan terdiri atas empat menu, yaitu (1) Al-Mufradat, (2) Al-Qiraah Al-Jahriyah, (3) Fahm Al-Maqru', dan (4) Al-Tadrib. Empat menu ini merupakan hasil pengembangan berdasarkan penetapan draf produk yang dilakukan melalui proses yang berulang-ulang (recursive) dengan melihat kebutuhan pengguna berdasarkan kurikulum Prodi S-1 PBA UM (reflective) bersama calon pengguna dan tim partisipan yang ahli di bidangnya (colaborative). Empat menu tersebut berisi program kegiatan membaca intensif bahasa Arab, karena jenis membaca yang dilatihkan pada Qiraah Tsanawiyah ini masih pada tingkat membaca intensif. Menurut Arini (2006) membaca intensif merupakan membaca secara cermat untuk memahami suatu teks atau isi bacaan secara tepat dan akurat (Murda \& Purwanti, 2017). Membaca intensif memerlukan pelatihan dan bimbingan secara intensif, bahan bacaan biasanya tidak panjang dan ditentukan oleh pengajar. Ada lima program kegiatan membaca intensif yang dikembangkan dalam media ini, yaitu (1) memahami makna kosakata, (2) memahami makna pola kalimat, (3) memahami struktur kalimat dalam teks, (4) menentukan ide pokok, dan (5) menguasai isi teks.

Setiap menu mengandung program kegiatan membaca. Pertama, menu Al-Mufradat berisi kumpulan kosakata dari setiap unit bacaan. Program kegiatan dalam menu Al-Mufradat ini terdiri atas dua latihan membaca, yaitu (1) membaca kosakata secara berulang sambil memahami maknanya melalui gambar dan (2) memahami makna kosakata melalui kamus. Latihan pemahaman kosakata ini perlu diberikan sebelum menuju kepada tahap pemahaman teks bacaan karena dengan memahami makna setiap kata maka memahami teks bacaan akan menjadi mudah. Semakin banyak kosakata yang mahasiswa kuasai maka semakin cepat pemahaman terhadap isi bacaan itu tercapai. Menurut Laufer (1989), Laufer \& Sim (1985), dan Nation (1990) kosakata adalah faktor yang paling penting dalam pemahaman bacaan (Baso et al., 2016). Pemahaman kosakata dalam media ini dilatihkan dengan bantuan gambar karena gambar memiliki daya visual tinggi yang dapat menarik minat dan motivasi seseorang dalam mencermati sebuah objek sehingga menghasilkan daya ingatan yang tahan lama. Penelitian (Fajriah, 2015) membuktikan bahwa penggunaan media kartu kata bergambar dapat meningkatkan penguasaan kosakata bahasa Arab (mufradat). Di samping melalui gambar, pemahaman kosakata dalam media ini juga diberikan melalui penyajian makna kata dari kamus untuk mengetahui arti kata yang lebih luas, baik dari segi sinonimnya atau antonimnya, bentuk singular atau pluralnya, maupun dari segi definisinya.

Kedua, menu Al-Qiraah Al-Jahriyah berisi kumpulan audio Qiraah Jahriyah (Qijah) dari setiap unit bacaan. Program kegiatan dalam menu ini terdiri atas dua latihan, yaitu (1) membaca kalimat secara jahriyah dengan benar dan (2) membaca gambar secara jahriyah dengan benar. Pada menu ini disediakan contoh audio untuk dijadikan model bagi siswa dalam melakukan Qijah dengan benar, baik dari segi kevalidan bunyi bacaan, kelancaran membaca, maupun intonasi, karena Qijah ini termasuk dalam kegiatan membaca intensif yang perlu mendapat perhatian. Di samping itu, berdasarkan pengalaman mengajar, masih ada beberapa mahasiswa yang kemampuan Qijahnya belum maksimal. Lebih dari itu, kemampuan Qijah sangat penting dibiasakan bagi pebelajar bahasa asing pada tahap awal belajar supaya mereka terbiasa mengucapkan dan membaca kata-kata bahasa Arab yang belum pernah mereka temui sebelumnya. Qijah adalah memvokalisasikan simbol-simbol bahasa Arab berupa kata, frase, klausa, kalimat, paragraf, maupun teks berbahasa Arab melalui membaca bersuara dengan pelafalan dan intonasi yang benar terlepas dari pemahaman makna simbol-simbol tersebut. Kemampuan Qijah yang baik dapat mendukung pebelajar mencapai tingkatan kemampuan membaca selanjutnya, yaitu pemahaman teks. Berdasarkan penelitian (Panjaitan et al., 2018) bahwa kemampuan membaca nyaring berdampak pada pemahaman isi bacaan secara keseluruhan dan menurutnya bahwa Reading Aloud (Qijah) dapat meminimalisir kesulitan membaca.

Ketiga, menu Fahm Al-Maqru ' berisi kumpulan teks bacaan dari setiap unit bacaan. Program kegiatan dalam menu Fahm Al-Maqru ' terdiri atas dua latihan, yaitu (1) membaca teks secara jahriyah (nyaring) dengan benar dan (2) membaca teks dengan metode diam sambil memahami intinya melalui bantuan gambar. Membaca diam adalah salah satu metode membaca tak bersuara dan dilakukan dalam hati untuk memahami bacaan. Membaca diam dalam Fahm Al-Maqru' ini penting karena saat membaca dalam hati mahasiswa dapat memusatkan perhatiannya terhadap pemahaman isi teks yang dibaca. Membaca diam termasuk metode yang tepat untuk memahami isi teks bacaan karena pada dasarnya membaca itu membutuhkan peran yang dominan dari pembaca itu sendiri. Membaca diam juga dapat menumbuhkan kebiasaan membaca (Ilma \& Ibrohim, 2020). 
Keempat, menu Al-Tadrib berisi kumpulan latihan dari setiap unit bacaan. Program kegiatan dalam menu Al-Tadrib ini melatih lima keterampilan membaca intensif berdasarkan kebutuhan kurikulum dan kebutuhan pengguna, yaitu (1) memahami makna kosakata, (2) memahami makna pola kalimat, (3) memahami struktur kalimat dalam teks, (4) menentukan ide pokok, dan (5) menguasai isi teks.

Keterampilan memahami makna kosakata terkait teks dikembangkan melalui empat jenis latihan, yaitu (a) menentukan makna kosakata dengan bantuan gambar, (b) menentukan makna kosakata melalui bentuk pluralnya (jama'), (c) menentukan makna kosakata melalui sinonim atau antonimnya, dan (d) menentukan makna kosakata melalui definisinya. Keterampilan memahami makna pola kalimat dikembangkan melalui dua jenis latihan, yaitu (a) mengidentifikasi pola kalimat dalam teks dan (b) mengidentifikasi kalimat yang berpola sama dengan pola kalimat dalam teks. Keterampilan memahami pola kalimat termasuk keterampilan yang berperan menentukan keberhasilan mahasiswa dalam memahami bacaan karena kalimat bahasa Arab memiliki beberapa pola yang tidak sama dengan bahasa ibu maupun bahasa pertama mahasiswa.

Keterampilan memahami struktur kalimat dalam teks dikembangkan melalui dua jenis latihan, yaitu (a) menjelaskan makna kalimat yang mengandung struktur tertentu dan (b) mengidentifikasi struktur kalimat tertentu dalam teks. Struktur kalimat yang dimaksud disini adalah materi yang berkaitan dengan tata bahasa Arab yang terdapat dalam teks, baik nahwu maupun sharaf. Keterampilan mengenal struktur kalimat yang dibaca juga dapat membantu mahasiswa dalam memahami isi bacaan. Penelitian Amir \& Rasmi (2019) membuktikan bahwa pembelajaran Qawaid Nahwu (Sintaksis bahasa Arab) memberikan kontribusi besar terhadap keterampilan membaca mahasiswa.

Keterampilan menentukan ide pokok dikembangkan melalui latihan mengidentifikasi ide pokok setiap paragraf. Keterampilan menentukan ide pokok setiap paragraf merupakan salah satu tolak ukur keberhasilan seseorang dalam memahami bacaan karena dengan mengetahui ide pokok setuap paragraf, pembaca dapat mengetahui inti bacaan, dan dengan mengetahui ide pokok setiap paragraf, pembaca dapat menyimpulkan isi bacaan. Salah satu pentingnya kemampuan menentukan ide pokok adalah memperoleh serta memanfaatkan ide-ide yang terdapat pada bacaan. Selain itu agar kita mengetahui maksud suatu bacaan dan mengetahui masalah pokok atau topik yang terdapat dalam bacaan. Ketika beberapa ide yang diperoleh dari bacaan dapat menyatu dengan pengalaman sebelumnya (skemata pembaca), akan berdampak pada munculnya konsep yang lebih luas (Saroh \& Damaianti, 2016). Berdasarkan pengalaman mengajar membaca bahasa Arab selama ini, keterampilan menentukan ide pokok paragraf jarang disentuh karena pembelajaran sering terpusat pada pemahaman isi teks secara harfiah melalui penerjemahan kosakata yang dianggap sulit dan terpusat pada membahas latihan soal terkait isi teks.

Adapun keterampilan menguasai isi teks dikembangkan melalui enam jenis latihan, yaitu (a) memahami isi teks, (b) menerjemahkan kalimat dalam teks, (c) menemukan fakta tersurat, (d) menemukan fakta tersirat, (e) memahami makna kalimat dengan bantuan gambar, dan (f) mengidentifikasi bukti sebuah pernyataan dari dalam teks. Keterampilan menguasai teks ini adalah tujuan utama dari kegiatan membaca. Seorang pembaca dapat dikatakan menguasai isi teks jika dapat mengerjakan enam latihan tersebut dengan baik.

Dari aspek bahasa, semua materi dalam media ini menggunakan bahasa Arab Fusha (baku) yang bersumber dari Kitab Al-'Arabiyah Baina Yadaik Jilid II, kamus pendamping Kitab Al-'Arabiyah Baina Yadaik, dan kamus elektronik Al-Ma'aniy. Ketiga sumber ini sudah valid dan tidak diragukan kesahihannya sehingga dari aspek bahasa media ini dapat dikatakan layak digunakan. Di samping itu media ini dikembangkan secara kolaboratif, yaitu melibatkan calon pengguna dan tim ahli di bidangnya secara aktif. Dari aspek grafis, media yang dihasilkan dalam pengembangan ini memperhatikan unsur-unsur grafis, yaitu penggunaan warna yang sesuai, kombinasi warna, pemilihan bentuk, penggunaan gambar, pengaturan tata letak, pemilihan jenis dan ukuran font, penentuan spasi, pengaturan background setiap tampilan, pemilihan logo, simbol , dan lambang, pemilihan tekstur, dan pengaturan media audio. Semua unsur tersebut diramu dan didesain melalui seleksi dan pemikiran yang matang supaya menghasilkan produk yang layak dari aspek grafis.

Beberapa contoh penerapan unsur grafis dalam media ini tampak pada desain cover media. Cover media ini bernuansa warna biru gelap dengan perpaduan warna biru keabu-abuan sehingga bernuansa warna biru yang harmonis. Di bagian tengah cover terdapat nama/judul media yang ditulis dengan bahasa Arab, yaitu القراءة عبر أندرويد (Al-Qiraah 'Abra Android) yang artinya dalam bahasa Indonesia adalah membaca melalui media Android, atau Reading Through Android jika dalam bahasa Inggris. Judul ini ditulis dengan warna putih sehingga tampak jelas dan cerah berada di atas warna background cover yang bernuansa biru gelap. Di samping untuk tujuan kemenarikan desain, pemilihan unsur grafis juga ada yang bertujuan untuk menyesuaikan dengan isinya, seperti penggunaan huruf Arab pada judul media, dipilih huruf Arab karena isi materinya adalah keterampilan membaca bahasa Arab. Di atas judul media terdapat logo UM sebagai tanda bahwa media pembelajaran ini merupakan salah satu produk inovasi pembelajaran yang dihasilkan oleh dosen UM dan digunakan untuk mahasiswa UM atas dukungan moril dan materil dari UM.

Semua pemilihan unsur grafis dalam media ini dilakukan sedemikian rupa supaya hasilnya layak digunakan tidak hanya dari aspek isi dan bahasa, namun juga dari aspek tampilan karena media pembelajaran yang baik itu seharusnya dapat memperhatikan aspek-aspek yang mampu memberikan ciri yang khas dari media tersebut, seperti aspek tampilan dan citra maupun unsur-unsur visual yang terstruktur sehingga mampu mewakili atau menggambarkan image dari apa yang ingin dicapai. (Maimunah et al., 2015). 


\section{SIMPULAN}

Penelitian pengembangan ini menghasilkan produk media android interaktif (Interactive Android Based Learning Media) untuk pembelajaran keterampilan membaca bahasa Arab tingkat intermediate (Qiraah Tsanawiyah) di perguruan tinggi. Media ini berisi empat menu utama, yaitu (1) menu Al-Mufradat, (2) menu Al-Qiraah Al-Jahriyah, (3) menu Fahm Al-Maqru', dan (4) menu Al-Tadrib. Keempat menu ini berisi program kegiatan membaca bahasa Arab yang dikembangkan untuk meningkatkan lima keterampilan membaca intensif, yaitu (1) memahami makna kosakata, (2) memahami makna pola kalimat, (3) memahami struktur kalimat dalam teks, (4) menentukan ide pokok, dan (5) menguasai isi teks. Lima program kegiatan membaca ini merupakan rangkaian kegiatan yang runtut, bertahap, terpadu, dan berkelanjutan mulai dari memahami kosakata, pola kalimat, struktur kalimat, ide pokok, sampai isi bacaan sehingga memudahkan mahasiswa untuk menghasilkan pemahaman menyeluruh terhadap isi teks.

Produk hasil pengembangan ini layak digunakan, baik dari aspek isi, bahasa, maupun grafis karena proses pengembangan produk ini menggunakan model yang sifatnya rekursif (ditelaah berulang-ulang), reflektif (melihat dan mempertimbangkan kebutuhan pengguna), dan kolaboratif (melibatkan calon pengguna dan tim ahli di bidangnya). Penelitian pengembangan menggunakan model R2D2 ini dapat disimpulkan efektif untuk digunakan mengembangkan produk pembelajaran yang tepat, efektif, efisien, dan relevan dengan kebutuhan pengguna meskipun tanpa tahap uji coba.

Penelitian pengembangan terkait media pembelajaran bahasa Arab perlu ditingkatkan terus supaya tingkat inovasi dan kreativitasnya semakin berkembang seiring dengan perkembangan teknologi pendidikan, karena penggunaan media yang tidak up to date akan tertinggal jauh dari produk media pembelajaran yang setiap saat terus berkembang. Penelitian pengembangan yang digunakan dalam memproduksi media pembelajaran perlu memanfaatkan model pengembangan yang tidak hanya sesuai dengan kebutuhan, situasi, dan kondisi dari pihak peneliti saja, namun juga perlu menyesuaikan pihak calon pengguna supaya hasilnya layak digunakan oleh mereka. Kualitas pembelajaran membaca bahasa Arab di perguruan tinggi harus ditingkatkan terus melalui program pengembangan inovasi pembelajaran, salah satunya adalah pengembangan media pembelajaran yang inovatif.

\section{DAFTAR RUJUKAN}

Alfan, M 2018) . يجاوى الثرقية إندونيسيا Doctoral dissertation, Universitas Islam Negeri Maulana Malik Ibrahim.

Amir, B., \& Rasmi, M. (2019). Kontribusi Pembelajaran Qawa>Id Nahwu Terhadap Keterampilan Membaca Mahasiswa Iain Bone. Didaktika: Jurnal Kependidikan, 13(2), 178-193.

Arindiono, R. Y., \& Ramadhani, N. (2013). Perancangan Media Pembelajaran Interaktif Matematika untuk siswa kelas 5 SD. Jurnal Sains dan Seni Pomits, 2(1), 28-32.

Baso, Y. S., Rahman, F., Haeruddin, H., \& Safa, N. A. (2016). Hubungan Penguasaan Mufradat dan Tingkat Pemahaman Membaca Teks Asli Bahasa Arab Mahasiswa. Arabi: Journal of Arabic Studies, 1(2), 50. https://doi.org/10.24865/ajas.v1i2.12

Dariyadi, M. W. (2019). Pembelajaran Bahasa Arab di Era Digital 4.0. Prosiding Konferensi Nasional Bahasa Arab V, 453.

Fajriah, Z. (2015). Peningkatan Penguasaan Kosakata Bahasa Arab (Mufradat) melalui Penggunaan Media Kartu Kata Bergambar. Jurnal Pendidikan Anak Usia Dini, 9(1), 107-126.

Haniifah, I. N., Kuswardono, K., \& Zukhaira. (2020). Magic Disc Arabic Berbasis Karakter Religius sebagai Media Pembelajaran Bahasa Arab untuk Keterampilan Membaca pada Siswa Kelas VII MTs di Kota Semarang. Lisan Al-Arab: Journal of Arabic Language and Arabic Teaching, 9(1), 15-22.

Hendrawanto, Ch. (2020). HOTS (Higher Order Thinking Skills ) Through SPPKB (Learning Strategy for Improving Thinking Ability) in Learning " Qiroah " Reading Skills Based on Contextual Learning as Implementation of $21^{\text {st }}$ Century Learning in Higher Education. Journal International Seminar on Languages, Literature, Arts, and Education (ISLLAE), 2(1), 2848.

Ilma, T., \& Ibrohim, B. (2020). Berbagai Kegiatan Membaca untuk Memicu Budaya Literasi di Sekolah Dasar. Primary: Jurnal Keilmuan dan Kependidikan Dasar, 12(1), 41. https://doi.org/10.32678/primary.v12i01.2708

Kusumadewi, N., \& Ulhusna, D. (2019). ISMIK (ISTIMA“e ASIK) Media Pembelajaran Berbasis Cross Cultural Understanding terhadap ketrampilan Menyimak Bahasa Arab Siswa MTS Kelas VII. In Prosiding (pp. 154-163).

Lin, M. H., Chen, H. C., \& Liu, K. S. (2017). A Study of the Effects of Digital Learning on Learning Motivation and Learning Outcome. Eurasia Journal of Mathematics, Science and Technology Education, 13(7), 3553-3564. https://doi.org/10.12973/eurasia.2017.00744a

Maimunah, Hadi, Y., \& Sartim. (2015). Desain Grafis untuk Media Promosi pada Nusantara English Centre. Proceedings Konferensi Nasional Sistem dan Informatika (KNS\&I), 1, 9-10.

Maita, I., Zarnelly, Z., \& Adawiyah, A. (2018). Pembelajaran Interatif Bahasa Arab Berbasis Android. Jurnal Ilmiah Rekayasa dan Manajemen Sistem Informasi, 4(2), 123. https://doi.org/10.24014/rmsi.v4i2.6227

Murda, N., \& Purwanti, P. D. (2017). Penerapan Strategi Pembelajaran Think Pair Share untuk Meningkatkan Kemampuan Membaca Intensif Siswa. International Journal of Elementary Education, 1(1), 11. https://doi.org/10.23887/ijee.v1i1.11434 
Ni'mah, K., Rizki, M. R., \& Ismawati, E. (2020). Implementasi Metode Takrir pada Materi Fi ' Il Dalam Pembelajaran Maharah Qiroah Bahasa Arab Siswa Kelas X SMK NU 1 Sukodadi. Al-Fakkaar, 1(2), 1-17.

Panjaitan, C. J., Hasanah, U., \& Langsa, I. (2018). Meminimalisir Kesulitan Membaca dengan Metode Reading Aloud pada Siswa MIN 1 Langsa. Seminar Nasional Royal (Senar) 2018, 9986(September), 547 - 552.

Putri, W. N., \& Billah, A. (2019). Pengembangan Media Pembelajaran Bahasa Arab berwawasan Sains berbasis Mobile Android. LISANIA: Journal of Arabic Education and Literature, 3(2), 163-179. https://doi.org/10.18326/lisania.v3i2.163179

Rayanto, Y. H. (2018). The Implementation of C-Id, R2D2 Model on Learning Reading Comprehension. Education of English as A Foreign Language, 1(1), 19-25. https://doi.org/10.21776/ub.educafl.2018.001.01.04

Saroh, E. R. S., \& Damaianti, V. S. (2016). Pengaruh Teknik Scramble terhadap Kemampuan. Eduhumaniora: Jurnal Pendidikan Dasar, 8(2), 144-151.

Suaibah, L., \& Rahman, T. (2020). Smart Tree Learning Media - We Can Be Based on Android for Arabic Subjects/ Media Pembelajaran Pohon Pintar-Kita Bisa Berbasis Android Untuk Matakuliah Bahasa Arab. Ijaz Arabi Journal of Arabic Learning, 3(1), 89-106. https://doi.org/10.18860/ijazarabi.v3i1.8215

Wijoyo, T. (2016). Pengembangan Media Pembelajaran E-Learning Berbasis Aplikasi Lectora Inspire untuk Keterampilan Membaca Bahasa Arab Siswa MTs Kelas VIII. Lisan Al-Arab: Journal of Arabic Language and Arabic Teaching, 5(1), 5-10. 